\title{
„Beka z nienormalsów", czyli satyryczny obraz niepełnosprawnych w kulturze masowej
}

AвSTRACT: Grzybowski Przemysław Paweł, Laughing at brainsicks - satiric image of disabled in mass culture ["Beka z nienormalsów”, czyli satyryczny obraz niepełnosprawnych w kulturze masowej]. Interdyscyplinarne Konteksty Pedagogiki Specjalnej, nr 6, Poznań 2014. Pp. 9-32. Adam Mickiewicz University Press. ISBN 978-83-232-2900-1. ISSN 2300-391X

In most societies disabled people are subject to taboo, in terms of laughing at their weaknesses, failures, inadequacies and differnt situations connected with their disability. However, they are becoming a more frequent ligtsome topic of different forms in mass culture (from television to the Internet) - interesting especially when they laugh at themselves. The article deals with the situations of laughing at Other in this context together with the examples of films, shows and educational projects.

KEY WORDS: The Other, outsiders, laugh, integration, mass culture, intercultural education

O czyjejś Inności lub Obcości decydują charakteryzujące człowieka właściwości pozwalające postrzegać siebie i pozostałe osoby przez pryzmat różnic kulturowych, socjalnych, ekonomicznych itp. ${ }^{1}$

${ }^{1}$ Szerzej na ten temat: M. Augé: Le sens des autres, Fayard, Paris 1994, s. 13-88; Z. Benedyktowicz, Portrety „obcego”, Wyd. Uniwersytetu Jagiellońskiego, Kraków 2000, s. 15-80; M. Dąbrowski: Swój/obcy/inny. Z problemów interferencji i komunikacji 
Jednak podstawą najprostszej i zarazem najczęstszej kategoryzacji są cechy biologiczne (wiek, płeć, wygląd zewnętrzny, niepełnosprawność fizyczna lub umysłowa itp.), na które wrażliwe są zwłaszcza dzieci i młodzież. Jedną z pierwszych reguł społecznych dotyczących śmiechu $w$ sferze publicznej jest rozpowszechniony $w$ wielu kulturach zakaz wyśmiewania rodziców oraz $\mathrm{w}$ ogóle ludzi i zwierząt starszych, nieszczęśliwych, chorych, cierpiących i z niepełnosprawnością. W większości społeczeństw szczególne ci ostatni podlegają zwyczajowemu tabu pod względem wyśmiewania ich słabości, niepowodzeń, przywar i rozmaitych sytuacji towarzyszących ich dysfunkcjom. Mimo to stanowią wdzięczny temat przekazu w kulturze masowej - interesujący zwłaszcza w sytuacji, gdy śmieją się sami z siebie. Celem niniejszej refleksji jest ukazanie okoliczności śmiechu z Innych w tym właśnie kontekście. Zakładam, że w przypadku osób z niepełnosprawnością, zwłaszcza w przypadku współczesnej satyry, mamy do czynienia z przenikaniem się dwóch rodzajów śmiechu: śmiechu z kogoś i śmiechu z kimś, przy czym będący obiektem śmiechu Inni zwykle zyskują w oczach odbiorców, co można wykorzystać w sferze edukacyjnej, choćby tylko w ramach kampanii społecznych służących integracji osób z niepełnosprawnością w danym środowisku².

\section{Śmiech z Innego w rodzinnej wspólnocie śmiechu}

Wiele związanych ze śmiechem zjawisk zachodzi na stykach pokoleń rodziców, dziadków i innych członków rodziny, co inspiruje całą rodzinną wspólnotę śmiechu, przede wszystkim jednak dzieci. Wówczas to dokonuje się rozróżnień komicznej twórczości

międzykulturowej, Świat Literacki, Izabelin 2001, s. 47-52; J. Kristeva, Etrangers á nous-memes, Fayard, Paris 1988, s. 9-248; B. Waldenfels, Topografia obcego. Studia z fenomenologii obcego, Oficyna Naukowa, Warszawa 2002, s. 11-40.

${ }^{2} \mathrm{~W}$ niniejszym opracowaniu wykorzystuję materiały zgromadzone na potrzeby monografii P.P. Grzybowskiego: Śmiech w edukacji. Od szkolnej wspólnoty śmiechu po edukacje międzykulturowa, Oficyna Wydawnicza „Impuls”, Kraków 2015. 
przeznaczonej dla dzieci i dorosłych, tematycznie i formalnie związanych $\mathrm{z}$ ich światami. Dzieci lubią się dzielić swym śmiechem $\mathrm{z}$ innymi. Sprawia im radość, że wciągnęły nową osobę do własnej wspólnoty śmiechu. W miarę dorastania i usamodzielniania się coraz większą rolę $\mathrm{w}$ ich życiu odgrywa rówieśnicza wspólnota śmiechu, początkowo będąca po prostu grupą wspólnej zabawy. Dziecko stopniowo zyskuje świadomość, że inne reguły występują we wspólnocie śmiechu, do której należą jego najbliżsi, inne zaś we wspólnocie rówieśniczej. Wiąże się to także z treścią żartów, dowcipów i sytuacji, które wywołują śmiech. Często dowcipy i żarty danego dziecka bywają zrozumiałe wyłącznie w jego małej, rodzinnej wspólnocie śmiechu, ponieważ wiążą się ze specyfiką wzajemnych relacji, języka, doświadczeń itp. Śmiech w ich życiu towarzyszy przede wszystkim zabawie, służąc odprężeniu, przezwyciężaniu strachu, obaw i integrując wspólnotę. Ewentualne ograniczenia treści i form komizmu wiążą się z rodzinnym światem wartości i przekazywane są $\mathrm{w}$ procesie socjalizacji.

Świadomy śmiech w kontaktach z Innymi pojawia się u dzieci w wieku przedszkolnym. Humor przedszkolaków uwarunkowany jest aktualnym stanem emocjonalnym. Reagują śmiechem na niemal wszelkie przeżywane stany radości, zabawy ruchowe, oglądane przedstawienia i filmy, podniecając się obserwowanymi bójkami. Zwykle nie zdają sobie sprawy $\mathrm{z}$ norm określających, $\mathrm{z}$ czego i w jakich okolicznościach wypada żartować i śmiać się. Poprzez żart wyrażają dezaprobatę wobec nielubianych osób i zjawisk, jednak rzadko żartują z osób lubianych i samych siebie. Dzieci w tym wieku nie lubią, gdy ktoś śmieje się $\mathrm{z}$ nich, ponieważ nie potrafią śmiać się z siebie samych. Ich dowcip często zawiera jednak dużo złośliwości, bywa okrutny i poniżający. Na tej zasadzie eksponują i ośmieszają postrzegane takie cechy fizyczne, jak wszelkiego rodzaju dysfunkcje, niedołęstwo, starość, zwłaszcza w kontekście odstępstw od popularnego $\mathrm{w}$ danym środowisku preferowanego wzorca wyglądu. Dzieciom w tym wieku śmieszne wydają się rzeczy wynaturzone i wręcz groteskowo przeistoczone, które trudno im ogarnąć $w$ ramach posiadanych schematów. Śmieją się więc, nie 
rozumiejąc, czym jest niepełnosprawność i karykaturalna w ich oczach brzydota Innych. Jednocześnie, nie umiejąc wczuć się w przeżycia osoby wyśmiewanej, za najbardziej komiczne uważają złośliwe żarty i przedrzeźnianie, chętnie je powtarzając i przedłużając, co niekiedy przybiera cechy raniącego szyderstwa i dręczenia. Niektóre dzieci wręcz bawią się kosztem ofiary i sycą jej cierpieniem. Bywają przekonane, że zyskają przez to uznanie środowiska, więc zachowują się kabotyńsko zarówno wobec rówieśników, jak i dorosłych. Złośliwość dziecięcych żartów uwarunkowana jest nieznajomością ich społecznego wydźwięku oraz poczuciem niższości wobec dorosłych. Chcąc wzmocnić efekt, dzieci posługują się też zwykle „brzydkimi wyrazami”. Obiektem tego rodzaju inwektyw bywają bardzo często niepełnosprawni Inni, zwłaszcza gdy nie słyszą małego szydercy. Podejmowane przez dorosłych próby bezwzględnego i natychmiastowego wykorzenienia takich zachowań nie dają rezultatów. Jedynym wyjściem jest stopniowe zastępowanie tego rodzaju poczucia humoru jego wyższą i szlachetniejszą formą ${ }^{3}$.

\section{Wyśmiewanie i satyra - nieodzowne elementy rzeczywistości społecznej}

Pierwszym kryterium wyodrębnienia jasno określonych rodzajów śmiechu jest zjawisko wyśmiewania. Mamy tu do czynienia ze śmiechem z kogoś lub z czegoś, często powiązanym z ośmieszaniem (tj. celowym działaniem, którego dąży do możliwie jak najdłuższego zachowania w pamięci społecznej faktu wyśmiania). Tego rodzaju śmiech jest przeciwieństwem radosnego śmiechu. Jest śmiechem agresywnym, złośliwym, skierowanym przeciwko (np.

3 Patrz: B. Dziemidok, O komizmie. Od Arystotelesa do dzisiaj, Słowo/Obraz/ Terytoria, Gdańsk 2009, s. 151; C. Matusewicz, Humor, dowcip, wychowanie - analiza psychospołeczna, Nasza Księgarnia, Warszawa 1976, s. 189; S. Szuman, Psychologia wychowawcza wieku dziecięcego, Instytut Wydawniczy Nasza Księgarnia, Warszawa 1947 , s. 175-176. 
Innym i Obcym) oraz obiektywnie postrzeganym jako negatywny. Społecznych następstw wyśmiewania i ośmieszania można doświadczać latami, jeśli pamięć o fakcie przetrwa w środowisku i nie zatrze jej jakieś pozytywne wydarzenie, śmierć ofiary i/lub sprawcy. W drastycznych przypadkach może być przekazywana z pokolenia na pokolenie jako element historii rodzinnej ${ }^{4}$. O tych dwóch rodzajach śmiechu mowa jest w Biblii (z hebr. sâhaq - pozytywny, radosny śmiech; lâhaq - wyśmiewanie, kpina), jak również w kulturze starożytnych Greków (odpowiednio z grec. gélân; katagélân) 5 . Platon (427 p.n.e.-437 p.n.e.) upatrywał źródła śmiechu w wyśmiewaniu innych i atakowaniu ich słabości, Arystoteles zaś (384 p.n.e.322 p.n.e.) w czerpaniu przyjemności z upokarzania i poniżania innych ${ }^{6}$.

Rozróżnienie to zostało dookreślone we współczesnej refleksji socjologicznej. Eugène Dupréel rozpatruje śmiech jako zachowanie społeczne, dialog między przynajmniej dwiema osobami, reakcję zbiorową na zjawiska komiczne. $W$ zależności od idei, charakteru tej reakcji wyróżnia śmiech przyjmujący (franc. rire d'accueil) i śmiech wykluczający (franc. rire d'exclusion). Śmiech przyjmujący wiąże się z tożsamością idei śmiejących się, z poczuciem wewnętrznej integracji ich wspólnoty śmiechu, nawet jeśli jest ona krótkotrwała i powstała spontanicznie wskutek zabawnego wydarzenia. Śmiech wykluczający pomaga izolować osoby poza wspólnotą śmiechu, wskazywać im „ich miejsce”, zwłaszcza gdy mamy do czynienia z trwałym i celowym procesem. Na tej zasadzie złośliwe wyśmiewanie i ośmieszanie zawsze opiera się na śmiechu wykluczającym 7 .

4 Patrz np.: A. Nguyen: Le rire et la derision, L'évolution Psychiatrique 1955, nr 2, s. 217-250.

5 Patrz: H. Lethierry, Potentialités de l'humour. Vers la "géloformation", L'Harmattan, Paris 2002, s. 99; G. Minois, Histoire du rire et de la derision, Fayard, Paris 2000, s. 39.

6 Patrz: A. Ziv, J.M. Diem, Le sens de l'humour, Dunod-Bordas, Paris 1987, s. 7.

7 Patrz: E. Dupréel, Le problème sociologique du rire, [w:] E. Dupréel, Essais pluralistes, Presses Universitaires de France, Paris 1949, s. 27-69. 
W polskiej refleksji nad śmiechem Juliusz Kleiner odróżnia śmiech z kogoś (śmiech złośliwy, wrogi) od śmiechu miłującego. Ów pierwszy rodzaj może być charakterystyczny dla sytuacji konfliktu i tryumfu, w której śmieje się pewny swego olbrzym, gdy chce mu stawić czoło ktoś mały i niepozorny. Ten ostatni śmieje się tym bardziej, gdy udaje mu się pokonać olbrzyma. Przeciwieństwem śmiechu złośliwego $\mathrm{z}$ kogoś jest śmiech miłujący, to znaczy pogodny, dobrotliwy, mądry, pełen humoru, życzliwości i przekonania, że mimo bólu i tragedii świat jest dobry. Komizm zawarty w zjawiskach i przedmiotach jest dla śmiejącego się powodem do okazywania im sympatii, serdecznego uśmiechania się do nich. Śmiejący się wprawdzie ma poczucie wyższości wobec spraw komicznych, lecz jednocześnie podchodzi do nich z ciepłem i optymizmem ${ }^{8}$. Sprowadzenie idei śmiechu i humoru na płaszczyznę aksjologii pozwala poszukiwać dobra $\mathrm{w}$ radosnym śmiechu miłującym, natomiast wiodącego do cierpienia zła w śmiechu złośliwym z kogoś, czyli w wyśmiewaniu.

Ponieważ ludzie często znają osoby, które z różnych powodów chcą wyśmiewać i lubią to robić, nie dziwi fakt, iż wyśmiewanie jest domeną komików. Śmiechem z kogoś lub czegoś jest zawsze satyra, której celem jest wywołanie pogardy, napiętnowanie, ukazanie w krzywym zwierciadle rzeczy lub osób postrzeganych przez twórcę jako niemoralne, złe, głupie itp. ${ }^{9}$ Tego rodzaju śmiech - zdaniem Henri Bergsona - powinien onieśmielać przez upokorzenie i karcić wady złoczyńcy, co wiąże się z jego ukrytym celem. Śmiech jest bowiem przede wszystkim środkiem poprawczym. Jego podstawową funkcją jest poniżanie, wskutek czego ma sprawiać karconej osobie przykrość. Za pomocą takiego śmiechu społeczeństwo mści się za swobodę, na jaką ktoś nieodpowiedzialnie sobie pozwolił.

8 Patrz: J. Kleiner, Z zagadnień komizmu, [w:] J. Kleiner, Studia z zakresu teorii literatury, Towarzystwo Naukowe Katolickiego Uniwersytetu Lubelskiego, Lublin 1956, s. 102-115.

9 Patrz: H. Sawecka, Humor i satyra: paradoks humorysty, [w:] M. Abramowicz, D. Bertrand, T. Stróżyński (red.), Humor europejski, Wyd. Uniwersytetu Marii Curie-Skłodowskiej, Lublin 1994, s. 24. 
Nie udałoby się uzyskać takiego efektu, gdyby śmiech zawierał cechy sympatii lub dobroci. Smiech staje się więc czynnikiem wywyższenia, poprawy samooceny śmiejącego się kosztem wyśmiewanego, poniżanego, pogardzanego. Pomaga pokazywać, że jest górą, jest lepszy, mądrzejszy, piękniejszy itp. i przez to dowartościowywać się. Taki śmiech może być środkiem poprawienia samopoczucia śmiejącego się i dokuczenia komuś, nawet tylko $\mathrm{w}$ sensie symbolicznym ${ }^{10}$. Komik Marcel Pagnol w swej koncepcji śmiechu uznaje tego rodzaju śmiech za pieśń tryumfu, wyraz chwilowej, jawnej wyższości prześmiewcy nad wyśmiewanym. Wyróżnia nawet dwa rodzaje takiego śmiechu: śmiech pozytywny - prawdziwy, zdrowy, toniczny (śmieję się, bo góruję nad światem, samym sobą i drugim człowiekiem) oraz śmiech negatywny brutalny, smutny, poniżający, mściwy (śmieję się, bo coś lub ktoś jest niższe ode mnie, bo mam nad tym przewagę) $)^{11}$.

Wyśmiewanie bywa jednym z narzędzi konfliktu, społecznego oporu, zarzewia rewolucji lub pospolitym elementem kultury masowej, w której agresywny śmiech stanowi o poziomie debaty publicznej. Będące jego formami kpiny, złośliwe dowcipy, szyderstwa i satyra są czynnikami osiągania społecznej higieny psychicznej poprzez rozładowywanie niezadowolenia, bezsilnego gniewu, oburzenia i kompleksów. Mogą również stanowić rekompensatę za niepowodzenia i rozczarowania, poniżenia, strach i klęski zarówno osobiste, grupy społecznej (np. Innych), jak i całego naro$\mathrm{du}^{12}$. Krytykowanie spraw publicznych za pomocą komicznych form jest jednym ze środków podnoszenia jakości kłopotliwych relacji społecznych. Komizm wykorzystywany w satyrze czy grotesce jest zwykle agresywny, ale u jego podstaw ostatecznie spoczywa dobro publiczne. Tego rodzaju krytyczny śmiech odgrywa rolę narzędzia $w$ relacjach między grupami, stanowi pryzmat

${ }^{10}$ Patrz: H. Bergson, Śmiech. Esej o komizmie, Wyd. KR, Warszawa 2000, s. 226.

${ }^{11}$ Patrz: H. Lethierry, Post-scriptum (la ballade des remords), [w:] H. Lethierry (red.), Savoir(s) en rire 3. Rire à l'école? (Expériences tout terrain), De Boeck Université, Louvain-Bruxelles 1997, s. 239-240.

12 Patrz: B. Dziemidok, O komizmie ..., dz. cyt., s. 142. 
akceptacji lub odrzucenia, podstawę nadawania wartości ludziom i zjawiskom. Pozwala też tworzyć, wzmacniać i integrować grupy poprzez przyczynianie się do powstawania wspólnot śmiechu13. Przedmiotem wyśmiewania nie tylko w sferze publicznej jest głupota, skąpstwo, chciwość, zazdrość, obłuda itp., to jest uniwersalne cechy obiektywnie piętnowane przez otoczenie od dawna. Obecność wyśmiewania tych cech w sztuce i kulturze masowej prowadzi do przekonania, iż mamy do czynienia z odwieczną postawą i zachowaniami uprawomocnionymi jako reakcje na ułomności natury ludzkiej - także rozpatrywanej w kategoriach niepełnosprawności. Takie podejście staje się niekiedy pretekstem do poczucia wyższości wyśmiewającego się jako kogoś, kto będąc intelektualnie i moralnie silniejszym, patrzy z góry na wyśmiewanych, ponieważ demaskuje ich niedostatki i złą naturę. Wyśmiewanie odgrywa więc rolę czynnika terapeutycznego, dzięki któremu w społeczeństwie klasyfikowane i piętnowane są osoby niepełnowartościowe wskutek swoich dysfunkcji ${ }^{14}$.

Satyra będąca formą negacji i dezaprobaty jest narzędziem społecznej krytyki, potępienia i ośmieszenia zła - choćby tylko dostrzegalnego w sferze publicznej. Będące jej podstawą wyśmiewanie stanowi formę kary mającej wywoływać u osoby czy instytucji będącej celem satyry (np. rządzących, prawodawców itp.) upokorzenie, wstyd i poczucie niezadowolenia z siebie. Ma odstraszać od niewłaściwego postępowania i mobilizować do poprawienia błędów, u obserwatorów zaś kształtować postawę krytycyzmu i bezkompromisowości wobec zła. Staje się szczególnie efektywnym narzędziem wobec wrogów, zwłaszcza wrogów wspólnych, publicznych. Wyśmiewanie wroga godzi w jego słabości (rzeczywiste lub wydumane), wydobywa na światło dzienne wszystko, co czyni go słabszym, niższym i gorszym niż się z pozoru wydaje. Nawet bardzo mocny przeciwnik traci wskutek wyśmiania pewność siebie, a jego uciśnionym, wyzyskiwanym i prześladowanym ofiarom po-

13 Patrz: A. Ziv, J.M. Diem, Le sens ..., dz. cyt., s. 6.

14 Patrz: K. Żygulski, Wspólnota śmiechu. Studium socjologiczne komizmu, PIW, Warszawa 1985, s. 268. 
prawia się samopoczucie ${ }^{15}$. Rozpatrywana $\mathrm{w}$ ten sposób satyra może być narzędziem w walce o prawa Innych, o ich integrację w środowisku.

\section{Inny jako tabu w kontekście wyśmiewania}

Niektóre przedmioty, zjawiska czy osoby mogą stanowić tabu, którego nie należy naruszać, wyśmiewając, jego naruszenie zaś może się wiązać z poważnymi sankcjami społecznymi (np. napiętnowanie czy wykluczenie wyśmiewającego). Wprawdzie twórczość komiczna nie zna ograniczeń i wszystko może być przedmiotem śmiechu, na przykład w sztuce, jednak pewne wartości bywają specjalnie chronione w sferze publicznej i tylko w niektórych wspólnotach śmiechu atak na nie nie spotyka się ze oporem czy sankcją. Zwykle wyśmiewanie świętości jest lokowane na pograniczach bądź marginesie społecznym, a wszelkie przejawy przekroczenia granic bywają potępiane i zwalczane, przynajmniej ze strony dominującej większości. W europejskim kręgu kulturowym najczęściej aprobowane przez większość tabu wiążą się ze sferą agresji i seksualności, dlatego też wiele żartów dotyczy właśnie tych sfer - na zasadzie: co jest zakazane, może być wyśmiane ${ }^{16}$. Nie do przyjęcia $\mathrm{w}$ niektórych środowiskach są żarty ze spraw związanych $\mathrm{z}$ religią i ideologią narodową (np. dowcipy o przywódcach religijnych i narodowych), niepełnosprawnością, nędzą i ułomnością materialną lub intelektualną itp. Charakterystyczne jest również, że właściwie nie ma dowcipów o matkach, a jeśli już się pojawiają, to budzą ambiwalentne reakcje.

Zwykle jednak tabu wiąże się ściśle z określonym środowiskiem. Oto na przykład satyryczny rysunek z Mahometem, który wywołał burzę z krajach muzułmańskich, przez większość Europej-

15 Patrz: B. Dziemidok, O komizmie ..., dz. cyt., s. 152-166.

16 Patrz: K. Żygulski, Wspólnota śmiechu ..., dz. cyt., s. 243-255; A. Ziv, J.M. Diem, Le sens ..., dz. cyt., s. 5. 
czyków (zwłaszcza niebędących muzułmanami) nie tylko nie został odebrany jako naruszający tabu, ale wręcz uznano go za wyłącznie niezbyt udany żart. W związku z tabu $\mathrm{w}$ niektórych sytuacjach $\mathrm{z}$ wyśmiewaniem wiążą się silne, przeciwstawne emocje, na co uwagę zwraca Mieczysław Wallis:

Uderza zwłaszcza, jak przeciwdziałają powstaniu przeżycia komizmu współczucie i litość. Znana jest anegdota o głuptasku, z którego na ulicy wszyscy się śmieją. Nie śmieje się tylko jeden człowiek - jego ojciec. Współczucie dla syna paraliżuje $\mathrm{w}$ nim bowiem poczucie komizmu. Człowiek kulejący - duch ulegający ciału - jest, w zasadzie, komiczny. Ale tylko ktoś gruboskórny może śmiać się z kuternogi. W człowieku subtelniejszym współczucie nie pozwala rozwinąć się uczuciu śmieszności. Bogowie olimpijscy, którzy na widok utykającego Hefajstosa wybuchają potężnym śmiechem, mają poczucie komizmu, ale nie mają ani serca, ani taktu' ${ }^{17}$.

Wyśmiewanie $\mathrm{w}$ takich sytuacjach staje się więc przedmiotem ocen oraz wartościowania wyśmiewających i ich czynów w kategoriach moralnych - przynajmniej w odniesieniu do obowiązujących wzorów i norm wychowania.

O ile dopuszczalny bywa śmiech z osoby pyszniącej się swą siłą, wiedzą lub stanowiskiem, bo pomaga $\mathrm{w}$ rozładowaniu kompleksu niższości, to kpiny ze słabszych i bezradnych są zdecydowanie źle widziane i zwracają się przeciwko wyśmiewającemu, który postrzegany jest co najmniej jako źle wychowany ${ }^{18}$. Wyśmiewanie rozpatrywane zarówno $\mathrm{w}$ formie bezpośredniego śmiechu z kogoś lub czegoś, a także w postaci żartów, dowcipów i kawałów skierowanych przeciwko określonym osobom, instytucjom lub zjawiskom mimo powszechności bywa jedną $\mathrm{z}$ treści wychowania. Lista zakazów w tym względzie jest długa, a hierarchię poszczególnych pozycji charakteryzuje dynamika - odpowiednio do miejsca i czasu.

${ }_{17}$ M. Wallis, O przedmiotach komicznych, [w:] M. Wallis (red.), Przeżycie i wartość. Pisma z estetyki i nauki o sztuce 1931-1949, Wyd. Literackie, Kraków 1968, s. 298.

18 Patrz: S. Garczyński, Śmiechu naszego powszedniego, Watra, Warszawa 1981, s. 61 . 


\section{„Beka z nienormalsów"19}

Kontrowersyjne, lecz zarazem interesujące $\mathrm{z}$ edukacyjnego punktu widzenia są przykłady naruszania tabu i wyśmiewania niepełnosprawności, zwłaszcza w kulturze masowej.



Ryc. 1. Przykład prowokacji w integracyjnej kampanii społecznej Źródło: Facebook [dostęp: 9.04.2015]

${ }^{19}$ Wykorzystuję tu potoczne kategorie pojęciowe funkcjonujące $\mathrm{w}$ środowisku zwłaszcza młodszych internautów. „Beka” to śmiech z kogoś lub z czegoś (np. beka ze szkoły, beka z obciachowych ciuchów itp.), „nienormalsi” zaś to kategoria wywodząca się od anglojęzycznego określenia normal - normalny, zwyczajny, w tym wypadku oznaczająca osoby, które z różnych przyczyn (np. niepełnosprawność) wykraczają poza normy obowiązujące w danym środowisku. 
Starożytny i średniowieczny śmiech nie znał tabu o ile pozwalał śmiejącym się uwolnić od strachu i trwogi - powodów, do których w tamtych czasach było sporo: choroby, wojny, mrok i oczywiście Bóg jako groźny sędzia i sprawca cierpienia. Jak piszą Anna Januszkiewicz i Marcin Rychlewski, trwogę przed Bogiem można

[...] bez zagubienia istoty rzeczy - zastąpić trwogą przed śmiercią, chorobą, nieszczęśliwym wypadkiem, kataklizmem czy atakiem terrorystycznym. Źródło lęku nierzadko przekształca się w społeczne tabu, uruchamiając efekt wyparcia lub zepchnięcia przedmiotu fobii do zbiorowej podświadomości. Śmiech stanowi tutaj z jednej strony próbę oswajania lęku, z drugiej zaś - jest manifestacją dystansu i poczucia wyższości wobec jego źródła ${ }^{20}$.

Stąd tak popularne w sztuce, zwłaszcza średniowiecznej, rzeźby zdobiące katedry i budynki, przedstawiające Innych i Obcych: chorych, ułomnych, cudzoziemców, zwykle o twarzach wykrzywionych w grymasie, o słabych członkach i wyraźnych oznakach niższości. Oto Inni oswojeni, wyzuci z cech, które mogłyby wywoływać strach. Kontynuację tej tendencji można dostrzec w późniejszym malarstwie Hieronima Boscha czy Pietera Breugela. Te dzieła sztuki stały się pierwszymi dostępnymi w różnym zakresie kanałami przekazu treści kultury masowej, a wyśmiewani w nich Inni nie tylko budzili zaciekawienie czy niechęć, ale pozwalali śmiejącym się odreagować własny strach.

Wisława Szymborska zwraca jednak uwagę na okrucieństwo ówczesnego śmiechu, do którego pretekstem stało się cierpienie zwierząt i osób z niepełnosprawnością:

[...] jak to się jednak dobrze składa, że straciliśmy zdolność rozumienia średniowiecznego komizmu! Nie ma czego żałować. Śmiano się wówczas z kalek, debilów i wariatów, brzydotę fizyczną uważano za przejaw brzydoty duchowej, na dworach trzymano karłów dla zabawy prymitywny humor zaiste. I tu przypomniał mi się hrabia d'Armagnac

${ }^{20}$ A. Januszkiewicz, M. Rychlewski, Czarna księga humoru. Dowcipy - autentyki makabreski, Vesper, Poznań 2011, s. 8-9. 
i zabawa, jaką w swoim paryskim pałacu wyprawił, a wiek był już, bądź co bądź, piętnasty. Sprosił ów hrabia gości, a na dziedziniec wypuścił wieprzka i czterech ślepców z kijami. Ślepcy mieli wieprzka zatłuc na śmierć; nagrodą było mięso. Podobno można było boki zrywać, kiedy ślepcy goniąc za kwiczącym wieprzkiem walili kijami przeważnie po sobie. He, he, hy, hy²1.

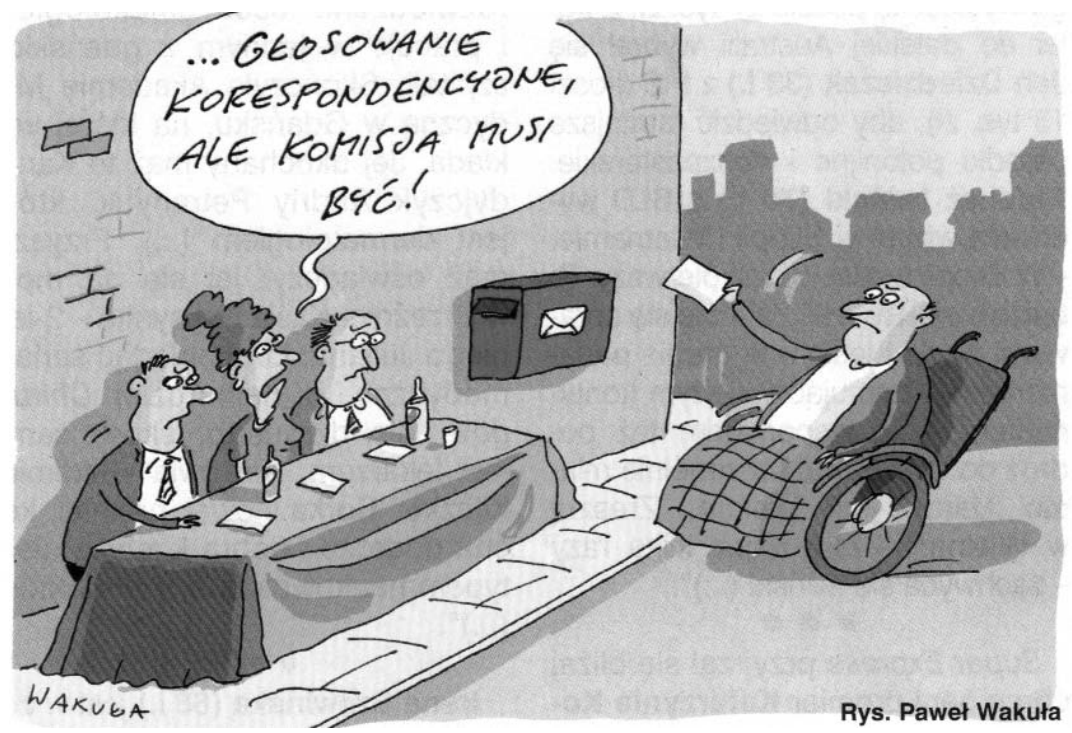

Ryc. 2. Przykład satyry przedwyborczej

Źródło: Facebook [dostęp: 9.04.2015]

Okrutny śmiech z niepełnosprawnych błaznów, dworskich karłów, Innych funkcjonujących w środowisku nędzarzy i plebsu to uosabiany przez Quasimoda, towarzyszący średniowiecznym świętom głupców i późniejszym karnawałom element kultury masowej22. W o wiele mniejszej skali (bo bez możliwości wyrządzania

${ }^{21}$ W. Szymborska, Lektury nadobowiązkowe. Część druga, Wyd. Literackie, Kraków 1981, s. 14.

22 Szerzej na ten temat: P.P. Grzybowski, Śmiech w edukacji..., dz. cyt., s. 118-134. 
fizycznej krzywdy) odziedziczyły go później tłumy bawiące się widokiem "ludzkich dziwadeł" pokazywanych w cyrkach (np. cyrk Phineasa Taylora Barnuma, który wyszukiwał i zatrudniał wyjątkowo „oryginalnych" niepełnosprawnych). Ten rodzaj śmiechu nie wiązał się już ze strachem, bowiem obiekt strachu nie jawił się jako niebezpieczny, zwłaszcza za kratami klatki. Śmiech ten towarzyszył dążeniom do poszukiwania dziwów i zaskakiwania, był następstwem zaskoczenia oraz tryumfu nad oswojeniem czegoś, co budzi niepewność.

Okiełznanie bezrefleksyjnego śmiechu z niepełnosprawności nastąpiło między innymi dzięki upowszechnieniu się literatury wychowawczej. Klementyna z Tańskich Hoffmanowa w powiastce Garbaty ustami rodziców bohaterów utworu przestrzega swych czytelników przed wyśmiewaniem upośledzenia:

Już dawno, moje dzieci, widzę w was brzydką skłonność do wyśmiewania się, i dawno was przestrzegam; wiem że ten wasz zwyczaj nie jest skutkiem złego serca, tylko zbytniej wesołości i nieuwagi. Bądźcie wesołe, dzieci moje, ale nigdy kosztem drugich; bo łatwo posądzą was o złość, która nie postała w duszach waszych! [...] Gdyby on sobie umyślnie takie garby porobił, odpowiedziała Matka, jak owe karykatury, któreście w warszawskim teatrze widziały, toby się z niego śmiać można; ale cóż on temu winien, że się takim urodził? Kiedy widzę jak gnie się pod ciężarem swego garbu i ledwie oddychać może, wzbudza we mnie najczulsze politowanie; a kiedy wiem, że pod tak niekształtną powierzchownością piękna ukrywa się dusza, szacunek przewyższa litość i nie pojmuję jakby się z niego naśmiewać można. [...] O! nietylko z pana Dobruckiego, ale z nikogo nie będziemy się śmieli, zawołały dzieci, bo zapewne każdy człowiek szpetny, każdy kaleka, prędzej politowania jak śmiechu jest godzien! Uściskali rodzice Antosia i Julisię za tę obietnicę z serca uczynionąą

Śmiech z kogoś lub z czegoś we współczesnej kulturze masowej niekoniecznie wynika ze strachu. Jest raczej środkiem przeciwko

${ }^{23}$ K. Tańska-Hoffmanowa, Garbaty, [w:] N. Żmichowska (red.), Dzieła Klementyny $z$ Tańskich Hoffmanowej, t. 2, Spółka Wydawnicza Księgarzy, Warszawa 1875, s. 14-15. 
nudzie, czynnikiem rozrywki czy walki ideologicznej - Inny zaś ofiarą lub tylko krótkotrwałym uczestnikiem przedstawienia, które trwa tak długo, jak długo budzi zainteresowanie widzów, słuchaczy, abonentów... „Beka z nienormalsów” to jednak nie tylko znak czasu świadczący o próbach przekraczania tabu, ale także czynnik walki z wykluczeniem, jeden z kontrowersyjnych, lecz efektywnych środków integracji Innych.



Ryc. 3. CP-Dockan. Lalka Goteborskiej Spółdzielni na rzecz Niezależnego Życia GIL Źródło: <www.gil.se>, [dostęp: 9.04.2015]

Osoby z niepełnosprawnością (lub kreowane na takie, choć nie zostało to jasno wyrażone) są ciepło przyjmowane przez miłośników literatury (np. Józef Szwejk)24, czy sztuki kabaretowej (np. Jaś

${ }^{24}$ Patrz: J. Hašek, Przygody dobrego wojaka Szwejka, Wyd. Zielona Sowa, Warszawa 2004. 
Fasola25, Benny Hill w skeczach o okularnikach i sepleniących ${ }^{26}$, paralityk i niewidomy w skeczach kabaretu Łowcy.B27, Kabaret Form Sierocych "Jurki", parodie niepełnosprawnych w wykonaniu kanadyjskiego komika Russella Petersa) ${ }^{28}$. Satyra na Innych, którzy $\mathrm{w}$ pozascenicznych okolicznościach byliby postrzegani jako obiekt tabu, w przypadku tych programów najczęściej nie razi, bo też nie zawiera szczególnych form ośmieszania i/lub wyszydzania, a jedynie prezentuje nieuniknione okoliczności wynikające z ludzkiej fizjologii, wieku i nieporadności. Tego rodzaju Inni wywołują raczej życzliwy uśmiech niż szyderczy śmiech, a satyra dotyczy raczej naiwnych i nieświadomych świadków perypetii głównych bohaterów, ci ostatni zaś budzą u widzów nie tyle litość, co sympatię. Dzieje się tak zwłaszcza, gdy działania sparodiowanych tu Innych wiodą do ukarania sprawców wszelkiego rodzaju niegodziwości i ograniczeń praw Innych lub przywodzą na myśl zjawiska znane widzom z autopsji, a w programie odtwarzane na zasadzie „znacie? to posłuchajcie!".

Osoby z niepełnosprawnością są też wdzięcznym tematem satyryków-rysowników. Poza tradycyjnym natrząsaniem się z niedołężnych staruszków czy niewidomych, z których najczęściej beztrosko (wręcz bezrefleksyjnie, a przynajmniej niekiedy daleko od empatii i dobrego smaku) żartuje się $\mathrm{w}$ prasie i na stronach internetowych, bywają przypadki wykorzystywania wizerunków Innych $\mathrm{w}$ krzywym zwierciadle $\mathrm{w}$ celu zwrócenia uwagi na ich potrzeby i kłopoty z pokonywaniem barier architektonicznych i społecznych. Tego rodzaju obrazki pojawiają się na przykład przy okazji towarzyszących wyborom parlamentarnym kampanii społecznych na

${ }^{25}$ R. Atkinson, Mr. Bean, Wielka Brytania 1990-1995.

26 B. Hill, Benny Hill, Wielka Brytania 1969-1989.

27 <www.lowcyb.pl>, [dostęp: 9.04.2015].

28 <www.russellpeters.com>, [dostęp: 9.04.2015]. Szerzej na ten temat: A. Bieganowska, "Kaleki humor” - pomaga, czy przeszkadza w ksztattowaniu postaw wobec osób niepetnosprawnych?, [w:] W. Świątkiewicz, M. Świątkiewicz-Mośny, W. Ślęzak-Tazbir W. (red.), Oblicza humoru, t. 1, Wyd. Tomasz Kalota Centrix, Wrocław 2007, s. 251-257. 
rzecz ułatwień dla osób z niepełnosprawnością czy akcji organizacji pozarządowych mających zwrócić uwagę na problemy wybranych grup osób specjalnej troski (np. chorych onkologicznie, ofiar wypadków itp.). W większości przypadków tego rodzaju satyry, komizm stanowiący jej podstawę nie jest złośliwy, lecz łagodny, a wizerunek Innych wyidealizowany, wręcz naiwny, co jednak nie przeszkadza w osiąganiu celów zakładanych przez organizatorów akcji, którym chodzi przede wszystkim o wywołanie pozytywnego nastawienia odbiorców i zwielokrotnienie informacji w środkach masowego komunikowania.

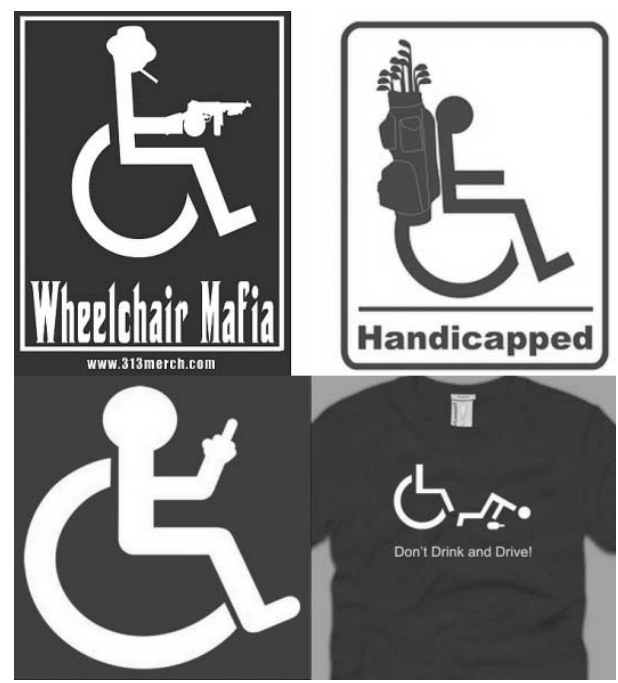

Ryc. 4. Przykłady wykorzystania symbolu niepełnosprawności w kulturze masowej Źródło: Facebook [dostęp: 9.04.2015]

Portale społecznościowe typu Facebook i zintegrowane z nimi aplikacje służące komunikacji (np. Twitter) czy publikowaniu i wymianie zdjęć (np. Instagram) pełne są rysunków satyrycznych, memów i znaków graficznych (np. zaczerpniętych ze wzorów koszulek, plakatów, naklejek, etykietek itp.), w których niepełno- 
sprawni Inni bywają ukazywani zwykle w pozytywnym świetle: jako ofiary barier architektonicznych i społecznych; "olbrzymy" walczący z własną słabością; równoprawni członkowie społeczeństwa; uczestnicy kampanii edukacyjnych na rzecz integracji itp. Rzadkością jest śmiech złośliwy, który mógłby zostać zakwalifikowany jako tabu. Nad stygmatyzującym rechotem hejterów przeważa życzliwy, rozumiejący śmiech z Innymi, a ich dysfunkcje i problemy wyśmiewane są $\mathrm{w}$ podtekstach ataku skierowanego do decydentów i twórców prawa. Każdego dnia na stronach internetowych zawierających rysunki satyryczne i dowcipy pojawiają się rozmaite treści, wśród których Inni ukazywani w różnych kontekstach nie są rzadkością.

Wiele kontrowersji czy wręcz negatywnych reakcji budzą przypadki, gdy to prawdziwi Inni z niepełnosprawnością są uczestnikami programów. Jedną z pierwszych głośnych w historii kultury masowej, wręcz legendarnych produkcji tego rodzaju był pełnometrażowy film „Dziwolągi” (ang. Freaks) z 1932 r., ${ }^{29}$ w którym w rolach głównych wystąpili: Wallace Ford, Leyla Hyams, Olga Baclanova i Rosco Ates. Film opowiada historię grupy cyrkowców, w której klasycznego wzrostu, piękna akrobatka obiecuje wyjść za mąż za karła, planując otrucie go i licząc na wysoki spadek po nim. Intrygę odkrywa grupa przyjaciół karła i postanawia zapobiec nieszczęściu. W filmie występuje plejada gwiazd cyrku charakteryzująca się rozmaitymi deformacjami. Tego rodzaju ludzkie „dziwolągi” od lat występowały w Cyrku Barnuma i wielu podobnych trupach na całym świecie. Tu zostały ukazane nie tylko ich problemy w codziennym życiu, ale także wiele zakulisowych zjawisk i procesów niedostępnych na co dzień miłośnikom cyrku i - szerzej - osobom nieobeznanym z niepełnosprawnością. Wiele scen, mimo że, jak to zwykle bywa $\mathrm{w}$ typowej hollywoodzkiej produkcji (film reklamowany był nawet jako dramat i horror), utrzymanych jest w satyrycznym duchu, budzi jednak refleksję i głęboki szacunek dla Inności bohaterów.

${ }^{29}$ T. Browning, Freaks, USA 1932. 
Pomysł zaangażowania do filmu artystów z niepełnosprawnością był później wielokrotnie powielany. W Polskiej kinematografii zapisał się paradokumentalny film Jacka Bławuta "Nienormalni”30, opowiadający historię nauczyciela muzyki pracującego $\mathrm{z}$ grupą dzieci niepełnosprawnych umysłowo. Film zdobył między innymi nagrodę specjalną za największe wydarzenie artystyczne na Festiwalu Polskich Filmów Fabularnych w Gdyni, Don Kichota - doroczną nagrodę Polskiej Federacji DKF, Nagrodę FIPRESCI Festiwalu w Mannheim, a także nominację do Europejskiej Nagrody Filmowej.

W podobnym duchu utrzymany jest współczesny, krótkometrażowy film "Motyli cyrk" (ang. The butterfly circus)31, w którym odtwórcą głównej roli jest Nick Vujicic, aktor pozbawiony rąk i nóg. Przesłaniem filmu jest idea poszukiwania wartości w sobie mimo ograniczeń, które w oczach innych mogą być dyskwalifikujące. Film, mimo niewątpliwie sentymentalnego podtekstu, jest postrzegany również jako satyra na wiecznie narzekających „zdrowych, pięknych i bogatych", którzy dopiero stając oko w oko z realnymi ograniczeniami, zdają sobie sprawę z ludzkich możliwości.

Mieszane uczucia widzów (o czym świadczą komentarze na forach internetowych) budzą produkcje, w których Inni wyśmiewają się z samych siebie i swych kłopotów. Przykładem jest fabularyzowany reality show "Wyjątkowi” (ang. The Specials) ${ }^{32}$, w którym występuje młodzież z zespołem Downa, śmiejąc się nie tyle z samych siebie, co z problemów współczesnych nastolatków. Kontrowersje widzów wiążą się z wątpliwościami, czy aktorzy wskutek swej niepełnosprawności umysłowej są $\mathrm{w}$ stanie zdawać sobie sprawę z komizmu niektórych scen. Budzi to pytania o etyczność tego popularnego programu oraz o granice przenikania satyry do obszaru tabu. $\mathrm{O}$ naruszenie tabu i przekroczenie granic $\mathrm{w}$ wyśmiewaniu niepełnosprawnych zostali oskarżeni twórcy filmu „Idioci”33, w którym:

\footnotetext{
30 J. Bławut, Nienormalni, Polska 1990.

31 J. Wegiel, The Butterfly circus, USA 2009.

32 <www.the-specials.com>, [dostęp: 9.04.2015].

33 L. von Trier, Idioterne, Dania, Francja, Hiszpania, Holandia, Szwecja, Włochy 1998.
} 
Grupa inteligentnych, wykształconych młodych ludzi przeprowadza oryginalny eksperyment: zamieszkują $\mathrm{w}$ tymczasowo pustej willi, należącej do wuja jednego z nich - przewodzącego grupie Stoffera, z zamiarem udawania ludzi psychicznie chorych. Poszukując ekstremalnych wrażeń, wyzbywają się wszelkich zahamowań, badają granice owej wolności, a jednocześnie świetnie się bawią, obserwując reakcje tzw. normalnych ludzi na ich rzekome kalectwo i bez skrupułów korzystają z wyrozumiałości, jaką otoczenie żywi dla niepełnosprawnych umysłowo ${ }^{34}$.

Nieco innego rodzaju wątpliwości budzą niepełnosprawni klauni w pracy socjalnej, którą wykonują nawet grupy niepełnosprawnych umysłowo w domach pomocy społecznej ${ }^{35}$.

Niekiedy Inni uczestniczą w kampaniach publicznych mających zwrócić uwagę na ich obecność w społeczeństwie lub pomóc w zbiórce funduszy na określony cel. Przykładem jest CP-Dockan wykrzywiona z paralitycznym skurczu lalka szwedzkiego stowarzyszenia osób z porażeniem mózgowym Goteborskiej Spółdzielni na rzecz Niezależnego Życia GIL (szwedz. Göteborgskooperativet för Independent Living) ${ }^{36}$. Na Facebooku lalka prezentowana jest między innymi z ustami pomazanymi piwną pianą, w stroju wampira lub czarownicy, na półkach sklepowych z "normalnymi” lalkami itp. ${ }^{37}$

Podobnych przykładów można by podać znacznie więcej. Wszystkie łączy idea śmiechu mimo wszystko, niekiedy śmiechu przez łzy lub do łez. Komercjalizacja kultury masowej i tendencja twórców do przekraczania kolejnych granic, byle by tylko zaskoczyć odbiorcę i zyskać nową publiczność, pozwalają przypuszczać, że tego rodzaju produkcji będzie więcej, a uczestnictwo w nich Innych z czasem przestanie budzić kontrowersje, o ile nie będzie naruszać zasady dobrego smaku czy jawnie godzić w tabu, których przekroczenie w określonych środowiskach mogłoby być zbyt dra-

34 <www.filmweb.pl/film/Idioci-1998-69/descs>, [dostęp: 9.04.2015].

35 Patrz: J. Plantet, Histoire de l'atelier Clownenroute: et si le rire était une affaire sérieuse, Lien Social 2001, nr 7, s. 4-10.

$36<w w w . g i l . s e>$, [dostęp: 9.04.2015].

37 <www.facebook.com/Cpdockan>, [dostęp: 9.04.2015]. 
styczne. Jednocześnie pozytywnie zaskakuje odbiór rozmaitych form satyry przez same osoby z niepełnosprawnością, które na ogół nie widzą w nich nic zdrożnego, o czym świadczą ich komentarze, choćby tylko na forach internetowych i grupach dyskusyjnych Facebooka. Pozostaje tylko wątpliwość, na ile zaangażowanie osób $\mathrm{z}$ niepełnosprawnością do działań artystycznych $\mathrm{w}$ przestrzeni publicznej przyczyni się do ich integracji. Być może chodzi tylko o show i przyciągnięcie uwagi widzów/słuchaczy/czytelników znudzonych „normalnością", których interesuje nie tyle świat Innych, co przekraczanie granic przez media ${ }^{38}$.

W sferze edukacji pozostaje więc nawiązywanie do idei międzykulturowości i poszukiwanie możliwości wykorzystania wspomnianych form satyry i im podobnych między innymi w ramach lekcji wychowawczych. Interesującym przykładem powiązania idei międzykulturowości i śmiechu, także w powyższym kontekście, jest karta małego humorysty opracowana przez uczniów francuskiej szkoły podstawowej. Nawiązanie do kwestii wyśmiewania, różnic rasowych, religijnych itp. czyni z tego dokumentu jedyny w swoim rodzaju manifest edukacji międzykulturowej przez śmiech:

Mamy prawo do żartowania, do bawienia się z przyjaciółmi, do śmiania się, gdy mamy na to ochotę i bez ograniczeń. Mamy prawo śmiać się bez przeszkadzania innym.

Deklarujemy, że humor pozwala zdobywać przyjaciół; pomagać komuś tak, by poczuł się lepiej; pozwala czuć się dobrze we własnej skórze. Humor dostarcza nam wytchnienia i uwalnia nas od stresu. Pociesza nas w niektórych kłopotach, a czasem czyni naszą codzienność bardziej interesującą; pomaga nam lepiej pracować, dodając nam zapału. Także dzięki humorowi jesteśmy radośni, szczęśliwi, jest nam dobrze razem; dzięki niemu możemy nawiązywać przyjemne relacje w dobrej atmosferze.

Twierdzimy też, że humor nie powinien być złośliwy czy obraźliwy. Nie powinien zawierać kpiny ani sprawiać przykrości. Nigdy nie powinien godzić w różnice, które istnieją między ludźmi. Nie będzie-

${ }^{38}$ Szerzej na ten temat: J. Szubrycht, Petno sprawnych, Polityka 2015, nr 22, s. $80-82$. 
my już żartować z czyjejś rasy, religii czy wyglądu. Nie będziemy już żartować z chorób, niepełnosprawności fizycznej lub psychicznej, ze stylu życia, myśli i poglądów innych ludzi, z ich nieporadności, nierozwagi ani też z zawodu, który wykonują, ich kultury, płci, biedy i pozycji społecznej.

Uważamy humor za dobrodziejstwo i możliwą broń. Będziemy się starać, by złym spojrzeniem nie doprowadzić nikogo do łez.

Dzieci z pierwszej klasy Szkoły Grandclément w Vaulx-en-Velin ${ }^{39}$.

Powyższy dokument może być podstawą głębokiej refleksji o granicach śmiechu, a raczej o okolicznościach poszukiwania form, które pozwolą złośliwy śmiech z kogoś zastępować radosnym śmiechem z kimś - także z Innymi.

\section{Bibliografia}

Annexe. Charte du petit humoriste, [w:] H. Lethierry (red.), Savoir(s) en rire 3. Rire à l'école? (Expériences tout terrain), De Boeck Université, Louvain-Bruxelles 1997. ATKINSON R., Mr. Bean, Wielka Brytania 1990-1995.

AugE M., Le sens des autres, Fayard, Paris 1994.

BENEDYKTOWICZ Z., Portrety „obcego", Wyd. Uniwersytetu Jagiellońskiego, Kraków 2000.

BERGSON H., Śmiech. Esej o komizmie, Wyd. KR, Warszawa 2000.

BIEGANOWSKA A., „Kaleki humor” - pomaga, czy przeszkadza w ksztattowaniu postaw wobec osób niepetnosprawnych?, [w:] W. Świątkiewicz, M. Świątkiewicz-Mośny, W. Ślęzak-Tazbir (red.), Oblicza humoru, t. 1, Wyd. Tomasz Kalota Centrix, Wrocław 2007.

BŁAWUT J., Nienormalni, Polska 1990.

BROWNING T., Freaks, USA 1932.

DĄBROWSKI M., Swój/obcy/inny. Z problemów interferencji i komunikacji międzykulturowej, Świat Literacki, Izabelin 2001.

DUPREEL E., Le problème sociologique du rire, [w:] E Dupréel, Essais pluralistes, Presses Universitaires de France, Paris 1949.

DZIEMIDOK B., O komizmie. Od Arystotelesa do dzisiaj, Słowo/Obraz/Terytoria, Gdańsk 2009.

${ }^{39}$ Annexe. Charte du petit humoriste, [w:] H. Lethierry (red.), Savoir(s) en rire 3. Rire à l'école? (Expériences tout terrain), De Boeck Université, Louvain-Bruxelles 1997, s. 242. 
GARCZYŃSKI S., Śmiechu naszego powszedniego, Watra, Warszawa 1981.

GRZYBOWSKI P.P., Śmiech w edukacji. Od szkolnej wspólnoty śmiechu po edukację międzykulturowa, Oficyna Wydawnicza „Impuls”, Kraków 2015.

HAŠEK J., Przygody dobrego wojaka Szwejka, Wyd. Zielona Sowa, Warszawa 2004.

HiLl B., Benny Hill, Wielka Brytania 1969-1989.

JANUSZKIEWICZ A., RYCHLEWSKI M., Czarna ksiega humoru. Dowcipy - autentyki makabreski, Vesper, Poznań 2011.

KLEINER J., Z zagadnień komizmu, [w:] J. Kleiner (red.), Studia z zakresu teorii literatury, Towarzystwo Naukowe Katolickiego Uniwersytetu Lubelskiego, Lublin 1956.

KRISTEVA J., Etrangers á nous-memes, Fayard, Paris 1988.

LETHIERRY H., Post-scriptum (la ballade des remords), [w:] H. Lethierry (red.), Savoir(s) en rire 3. Rire à l'école? (Expériences tout terrain), De Boeck Université, LouvainBruxelles 1997.

LETHIERRY H., Potentialités de l'humour. Vers la "géloformation", L'Harmattan, Paris 2002.

MATUSEWICZ C., Humor, dowcip, wychowanie - analiza psychospołeczna, Nasza Księgarnia, Warszawa 1976.

MINOIS G., Histoire du rire et de la derision, Fayard, Paris 2000.

NGUYEN A., Le rire et la derision, L'évolution Psychiatrique 1955, nr 2.

PLANTET J., Histoire de l'atelier Clownenroute: et si le rire était une affaire sérieuse, Lien Social 2001, nr 7.

SAWECKA H., Humor i satyra: paradoks humorysty, [w:] M. Abramowicz, D. Bertrand, T. Stróżyński (red.), Humor europejski, Wyd. Uniwersytetu Marii Curie-Skłodowskiej, Lublin 1994.

SZUBRYCHT J., Petno sprawnych, Polityka 2015, nr 22.

SZUMAN S., Psychologia wychowawcza wieku dziecięcego, Instytut Wydawniczy Nasza Księgarnia, Warszawa 1947.

SZYMBORSKA W., Lektury nadobowiazkowe. Część druga, Wyd. Literackie, Kraków 1981.

TAŃSKA-HoFfMANOWA K., Garbaty, [w:] N. Żmichowska (red.), Dzieła Klementyny

$z$ Tańskich Hoffmanowej, t. 2, Spółka Wydawnicza Księgarzy, Warszawa 1875.

TRIER L. VON, Idioterne, Dania, Francja, Hiszpania, Holandia, Szwecja, Włochy 1998.

WALDENFELS B., Topografia obcego. Studia z fenomenologii obcego, Oficyna Naukowa, Warszawa 2002.

WALLIS M., O przedmiotach komicznych, [w:] M. Wallis (red.), Przeżycie i wartość. Pisma z estetyki i nauki o sztuce 1931-1949, Wyd. Literackie, Kraków 1968.

WEGIEL J., The Butterfly circus, USA 2009.

$<$ www.facebook.com/Cpdockan>, [dostęp: 9.04.2015].

<www.filmweb.pl/film/Idioci-1998-69/descs>, [dostęp: 9.04.2015].

<www.gil.se>, [dostęp: 9.04.2015].

<www.lowcyb.pl>, [dostęp: 9.04.2015]. 
$<w w w . r u s s e l l p e t e r s . c o m>$, [dostęp: 9.04.2015].

<www.the-specials.com>, [dostęp: 9.04.2015].

ZIV A., DIEM J.M., Le sens de l'humour, Dunod-Bordas, Paris 1987.

ŻYGULSKI K., Wspólnota śmiechu. Studium socjologiczne komizmu, PIW, Warszawa 1985. 